Ethiopian Journal of Environmental Studies \& Management 8(4): 451 - 463, 2015.

ISSN:1998-0507

doi: http://dx.doi.org/10.4314/ejesm.v8i4.10

Submitted: March 06, 2015

Accepted: May 06, 2015

\title{
HEAVY METALS AND PROXIMATE COMPOSITION OF FOREST LEAFY VEGETABLES IN OIL PRODUCING AREA OF NIGERIA
}

*OLADELE A.T. ${ }^{1}$ AND FADARE 0.0. ${ }^{2}$

${ }^{1}$ Department of Forestry and Wildlife Management, University of Port Harcourt, Nigeria

${ }^{2}$ Department of Pharmacognosy, Obafemi Awolowo University, Ile-Ife, Nigeria

\begin{abstract}
This work investigated heavy metals content of Forest Leafy Vegetables (FLVs) consumed in Port Harcourt, Nigeria. Fresh samples of eight commonly consumed FLV species were obtained from two major markets in Port Harcourt. FLVs were dried, digested and analysed with flame Atomic Absorption Spectrophotometer (AAS) for heavy metals. Proximate analysis of FLVs was carried out using standard method of AOAC. Concentrations of Iron (Fe) ranged from 4.69ppm (Heinsia crinata) - 8.97ppm (Gongronema latifolia), Manganese was highest in Liasanthera africana (6.03ppm) and lowest in O.gratissimum (0.45ppm) while Magnesium levels ranged from 0.609 - 1.630ppm. P.guineense accumulate highest $\mathrm{Pb}$ (1.004ppm) compared to Ocimum basilicum Pb (0.380ppm). Copper was highest in H.crinata (1.165ppm) and lowest in O.gratissimum $(0.218 \mathrm{ppm})$. O. gratissimum had lowest Cadmium (0.022ppm), Arsenic (0.003ppm), Mercury (0.002ppm) and Zinc (0.044ppm). P.guineense contains highest concentration of Chromium (3.792ppm) while $\mathrm{H}$. crinata possess the lowest (0.409ppm). Nickel was highest in O.bassilicum (0.665ppm) and least in G.latifolia (0.388ppm). FLVs were rich in crude protein, fat and crude fibre. O.bassilicum (21.00\%) was the richest in crude protein while H.crinata has the lowest level (11.55\%). Crude fibre content of the FLVs range from $11.0 \%$ to $14.0 \%$ while fat content varied between $2.4 \%$ for O.bassilicum and $4.0 \%$ for $\mathrm{H}$. crinata. FLVs sourced from natural forests in crude oil exploration areas in Nigeria is safe for consumption, since heavy metals of FLVs samples were less than maximum limits recommended by FAO/WHO. Proximate analyses showed that the FLVs possess useful nutritional contents required for healthy growth.
\end{abstract}

Key Words: Forest leafy vegetables, Heavy metals, Proximate composition, Nigeria

\section{Introduction}

In most developing tropical nations of sub Saharan West Africa, wild plant resources play significant role in food supply and other livelihood support (Sobukola et al., 2007; Mohammed and Sharif, 2011). Leafy vegetables are essential diet components providing protein, vitamins, iron, calcium and other nutrients, which are usually in short supply among the populations of poor tropical nations (Thompson and Kelly, 1999). Forest leafy vegetables (FLV) are usually gathered freely from the forests by the rural populations in the sub Saharan West African region for domestic consumption 
and sometimes for sale to supplement important for food security and poverty alleviation in the rural and peri-urban centres in Nigeria and many other rural parts of the world (Sundriyal et al. 2003; Oladele et al., 2013). FLV also supply the body with vitamins, proteins, energy, minerals and some hormone precursors (Akubugwo et al., 2007). Low socioeconomic status women have been implicated for collecting wild plants for vegetables (for domestic consumption and family income) in Nepal (Acharya and Acharya, 2010). Supply of animal protein in developing West Africa is inadequate and unaffordable by vast majority of people hence, alternatives in form of plant proteins are sourced from nearby forests. FLVs are a major source of plant protein to supplement poor supply of animal proteins and other essential minerals required for normal human health and development. Many of the FLVs such as Pterocarpous spp., Gnetum africana, Gongronema latifolia and Piper guineense are rich in fibre, fat and crude protein required for normal human physiological growth and healthy living. Most of FLVs are consumed fresh while some are dried and stored for future use. Redzic (2006) observed that wild plants are commonly used as a supplement for healthy diets in most developed regions of the world presently. Burlingame (2000) argued that some FLVs can be nutritionally superior to cultivated ones in many cases. The relevance of this important NonTimber Forest Products (NTFPs) in the livelihood of rural and urban populations cannot be over stressed especially in the dry season when cultivated vegetables such as Telfairia occidentales, Amaranthus hybridus and Celosia species become insufficient to meet the demand for vegetables throughout the year. Production family income. These vegetables are of these agronomic vegetables relied mostly on rainfed agriculture due to scanty irrigation facilities hence, forest leafy vegetables are essential to the survival of the teeming population. FLVs are crucial in traditional health care systems in rural West African communities. Vast majority of people live in rural areas and depend on medicinal plants for health care delivery due to poverty and non-availability of modern health care facilities (Amri and Kisangau, 2012). FLVs such as Pipers guineense, Gongronema latifolia, Ocimum spp have been documented as antimalarial plants in local herbal medicines in Nigeria (Oladele and Adewumi, 2008; Chima et al., 2013). Most FLVs in southern Nigeria are utilized as food and medicine for prevalent diseases such as malaria.

Heavy metals are natural components of the environment; however, human activities such as crude oil exploration, mining, industry and commercial agriculture have been linked to increased quantity of these elements in the environment (Yebpella et al., 2011). Studies of heavy metals in ecosystem indicated that many areas near urban complexes, metal ferrous mines and major road systems contain anomalously high concentrations of these elements. In particular, soil in such regions have been polluted from a range of sources with $\mathrm{Pb}$, $\mathrm{Cd}, \mathrm{Hg}$, As and other heavy metals (Nriagu, 1989). FLVs absorb heavy metals from contaminated soils and waters. Contamination of plants with toxic chemical elements due to contaminated soil and water has been observed as a result of the release of these toxicants into the sea, rivers, lakes and irrigation channels (Cambra et al., 1999). Soil pollutants affect micro flora and fauna of the ecosystem and 
also contaminate fruits and vegetables from such soils (Pande and Sharma, 1999; Kaur and Katnoria, 2014). Consumption of contaminated plants and plant products by man results in bioaccumulation of these metals in human body, this poses health risk both in short and long - term (Nordberg, 2004; Watanable et al., 2005). Heavy metals get into human body through food, water, air and skin absorption. Expansion of crude oil exploitation in Nigeria is associated with incessant oil spillage, water, soil and air pollution with heavy metals. Rivers State is a major hub of crude oil exploitation in Nigeria, oil exploration and associated activities usually predispose forest ecosystems to environmental hazards. Heavy metals such as Lead $(\mathrm{Pb})$, Zinc ( $\mathrm{Zn})$, Cadmium $(\mathrm{Cd})$, Chromium $(\mathrm{Cr})$, Copper $(\mathrm{Cu})$, Iron $(\mathrm{Fe})$, Aluminum (Al) and Manganese $(\mathrm{Mn})$ in various degrees have been reported in cow meat reared in polluted areas, fish from contaminated waters, cultivated vegetables and fruits from environmentally hazardous ecosystems in Nigeria (Agatha, 2011; Ogabiela et al., 2011; Yebpella et al., 2011; Nwoko, 2014). Scientific reports exists on the heavy metals analysis of cultivated vegetables in oil exploration areas in Nigeria, however, there is paucity of information on the toxic metals analysis of frequently marketed and consumed FLVs harvested from ecosystems under crude oil exploration in relation to their health risks on the consumers of such products. In this work we aim to document the heavy metals content of FLVs marketed and consumed in Rivers State, Nigeria and possible implications on the health of rural and urban consumers with a view to create awareness, sensitize formulation of appropriate health policy and improved welfare of inhabitants.

\section{Methodology}

Study Area

Rivers State is situated between latitude $4^{\circ} 45^{\prime} \mathrm{N} 6^{\circ} 50^{\prime} \mathrm{E}$ and longitude $4.75^{\circ} \mathrm{N}$ $6.833^{\circ} \mathrm{E}$ of Greenwich Meridian in the Niger Delta region of Nigeria. It is bounded in the south by the Atlantic Ocean, Delta, Abia and Akwa-Ibom states in the west, north and east respectively. The administrative headquarters is situated in Port Harcourt. Rivers State is endowed with abundance of crude oil deposit both onshore and offshore which the national economy hinged on since its' discovery in the 1960s. Exploration and refinery of crude petroleum resources have attracted several professionals and expatriates from different fields into the state to service the industry.

Oil wells and flow stations are located across the state. Water, air and soil pollution occur frequently following unrestricted gas flaring and oil spillage throughout the state. Port Harcourt, the capital city has witnessed tremendous growth in human population of different nationals and it is expanding in an unprecedented rate due to urbanization. The traditional subsistence farming and fishing of the local inhabitants have gradually given way to improved commercial activities in the metropolitan. Supplies of fresh fruits and vegetables suchas Musa species (plantain and banana), Solanum species (egg-plants), Telfairia occidentales (fluted pumpkin), Talinum triangulare (water leaf), Gnetum africana, Pipers guinense, Ocimum species (Basils) etc. come from towns surrounding the state capital. Rivers state is characteristics of two vegetation types: Salty mangrove forest and fresh water swamp tropical forest. Environmental pollution from oil spillage and gas flaring is a major challenge for the sustainable management of flora and fauna resources; several acres of forest cover and 
numerous aquatic organisms have been lost to oil exploration activities (Agatha, 2011).

\section{Sample Preparation and Analysis}

Fresh samples of eight (8) commonly consumed forest leafy vegetable (FLV) species were obtained from two major markets in Port Harcourt (Mile 1 and Oil mill markets) as indicated in Figure 1. Vegetable samples were thoroughly washed to remove all adhered soil particles in the laboratory, Department of Forestry and Wildlife Management, University of Port Harcourt. One hundred grammes (100gm) each of samples from the two markets were weighed for processing. Samples were cut into small pieces, air dried in the laboratory and same species bulked together for analysis. FLVs samples were mixed to form a composite of the particular species.
The samples were pulverised and passed through $1 \mathrm{~mm}$ sieve. Samples were taken to Soil Science laboratory, University of Ibadan, Nigeria for Flame Atomic Absorption Spectrophotometer analysis (FAAS) using Buck Scientific 210/211VGP model - USA. Samples were ashed at $550^{\circ} \mathrm{C}$ for 48 hours; wet digestion of ash samples (1g each) was carried out using 5 $\mathrm{ml}$ of concentrated nitric acid, according to Awofolu (2005). The mixture was filtered and the filtrate of $50 \mathrm{ml}$ in the standard flask with deionized water used in standardization of solution. Total of twelve heavy metals were investigated for their concentrations in the FLVs using AAS. Samples of FLVs were analysed for crude protein, fat, fibre and ash using standard method of AOAC (1995).

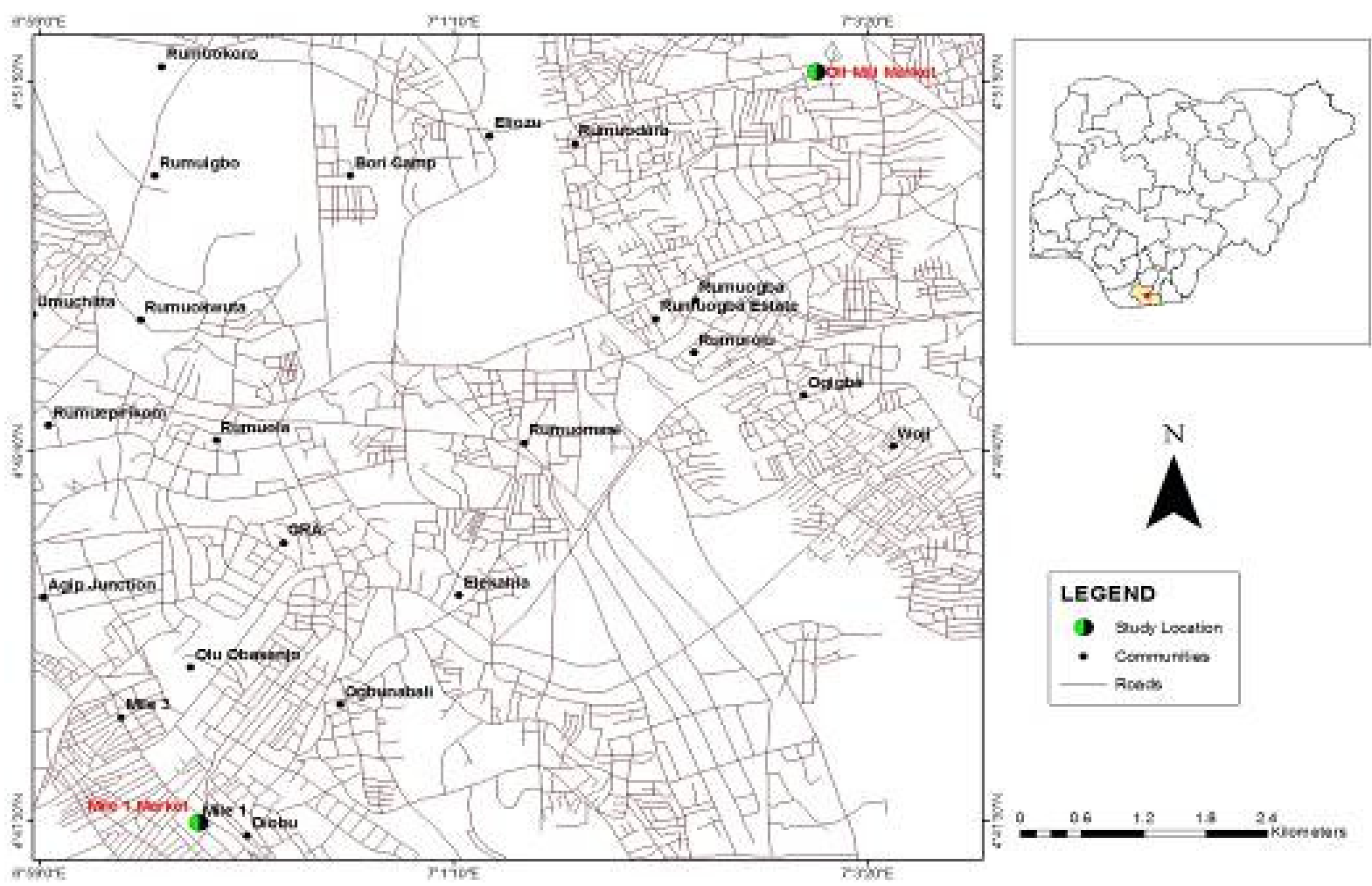

Figure 1: Map of Port Harcourt, Nigeria showing the study sites

\section{Results and Discussions}

Heavy metals concentrations in marketed and commonly consumed FLVs were shown in Table 1. Leaves of $G$. latifolia and $O$. gratissimum possess the highest concentrations of Iron (Fe) in their tissues with 8.97 and $8.87 \mathrm{ppm}$ respectively, Heinsia crinata contained the least $\mathrm{Fe}$ 
concentration (4.69ppm) among the eight FLVs investigated. Manganese was highest in Liasanthera africana leaves (6.03 ppm) and lowest in Ocimum gratissimum (0.45ppm) while Magnesium levels ranged from $0.609-1.630 \mathrm{ppm}$ in the commonly consumed FLVs. The leaves of Piper guineense accumulate highest concentration of Lead (Pb-1.004ppm) compared to the least $\mathrm{Pb}$ (0.380ppm) concentration in Ocimum bassilicum leaves. Copper $(\mathrm{Cu})$ is highest in $H$. crinata (1.165ppm) while $O$. gratissimum showed the lowest level of $\mathrm{Cu}(0.218 \mathrm{ppm})$. $O$. gratissimum also showed lowest concentrations in Cadmium (0.022ppm), Arsenic (As - 0.003ppm), Mercury (Hg$0.002 \mathrm{ppm})$ and Zinc (Zn-0.044ppm). $P$. guineense contains highest concentration of Chromium (3.792ppm) in its' leaves while $H$. crinata leaves possess the lowest level of Cr. (0.409ppm) and highest level of Selenium (0.066ppm). Nickel accumulation was highest in $O$. bassilicum $(0.665 \mathrm{ppm})$ and least in $G$. latifolia $(0.388 \mathrm{ppm})$ leaves. Pterocarpus soyauxii has medium accumulation of heavy metals investigated among the marketed FLVs in the study. Khanna and Khanna (2011) noted that potentially toxic metals uptake by plants generally is influenced by soil factors such as $\mathrm{pH}$ and plant physiologic factors. Cadmium is readily available for absorption in neutral or alkaline soils.

Iron $(\mathrm{Fe})$ is an essential element in human nutrition. Minimum daily requirement depend on age, sex, physiological status, and iron bioavailability and range from about 10 to $50 \mathrm{mg} /$ day. Established provisional maximum tolerable daily intake (PMTDI) of $0.8 \mathrm{mg} / \mathrm{kg}$ of body weight applies to iron from all sources (JECFA, 2005). Iron is an essential part of the haemoglobin in human blood, it is also found in the myoglobin of muscle cells. Iron is needed for transporting oxygen and carbon dioxide. Its' deficiency in humans leads to anaemia while excess of iron beyond $48 \mathrm{mg} /$ day have critical gastrointestinal side effects (Driskell, 2009). Impaired zinc absorption, vascular disease and cancer and systemic iron overload may be associated with iron toxicity in human body. Iron accumulation was highest in Gongronema latifolia $(8.97 \mathrm{mg} / \mathrm{kg})$ and lowest in Heinsia crinata $(4.69 \mathrm{mg} / \mathrm{kg})$. Iron concentration values obtained for all the forest leafy vegetables in the study were below the upper level daily intake for adults (48mg/day). Presence of chelators such as ascorbic acid and oxalate has been reported to reduce iron absorption in human meals (Aboderin et al., 2010). Although, commonly consumed forest leafy vegetables in this study contributes to sources of iron in human diets, other sources of iron are required to meet the minimum daily requirements for proper healthy living.

Manganese (Mn) is crucial and very important in human physiology, it is essential for haemoglobin formation. However, quantity of Manganese requirement in the body is small compared to iron; daily requirement for healthy living is $4.5 \mathrm{mg}$ (Sekeroglu et al., 2006). FLVs results showed highest concentration of Manganese in Liasanthera africana $(6.03 \mathrm{mg} / \mathrm{kg})$ which is below the tolerable daily intake of $12 \mathrm{mg} /$ day. All the FLVs showed lower levels of Manganese below the allowable daily intake.

Leafy vegetables from open field have been documented to possess higher concentrations of Lead $(\mathrm{Pb})$ than vegetables grown in green houses (Song et al., 2009). About $50 \%$ of $\mathrm{Pb}$ intake by man comes from drinking water due to its high solubility in water ((Singh and Kumar, 2006). Plants absorb $\mathrm{Pb}$ from deposits on the leaves and other exposed parts to polluted environments, vegetables such as 
carrot and cabbage was observed to take up Lead and Cadmium in contaminated soils from irrigation water in Ghana (Mensah et al., 2008). $\mathrm{Pb}$ posed high health risk to man especially infants and young children; there is no established health benefit of $\mathrm{Pb}$ in human body. Young children up to six years and pregnant women face adverse health effects from $\mathrm{Pb}$ while it is capable of increasing blood pressure and possibly ignite cancer in adults (Khanna and Khanna, 2011; Satsananan, 2014). High gastrointestinal uptake and permeable blood-brain barrier have been documented to predispose children to lead and some other heavy metals exposure, consequently resulting in great health risk (Jarup, 2003). JECFA recommended provisional tolerable weekly intake $25 \mu \mathrm{g} / \mathrm{kg}$ of body weight (equivalent to $3.5 \mu \mathrm{g} / \mathrm{kg}$ of body weight per day) for infants and children and $0.005 \mathrm{mg} / \mathrm{kg}$ body weight per day in adults. Permissible total daily intake (PTDI) of 3.57 ( $\mu \mathrm{g} /(\mathrm{kg}$ body weight per day) suggested for lead (FAO/WHO, 2001) was higher than concentration levels in all the FLVs used in this study. Results from the present study showed that FLVs marketed in Port Harcourt, Nigeria do not pose health hazards to the consumers presently regarding associated health issues linked to lead contamination in forest vegetables.

Copper $(\mathrm{Cu})$ is essential to human life as metalloproteins and function as enzymes, however, critical doses leads to health risks such as anemia, diabetes, inflammation, kidney and liver dysfunction and vitamin $\mathrm{C}$ deficiency (Lokeshappa et $a l .$, 2012). JECFA suggested safe limits of $40 \mathrm{mg} / \mathrm{kg}$ in adults (FAO/WHO, 2001). Maximum copper levels in FLVs obtained in this study (Table 1) fall below the safe limits recommended, hence FLVs in the study area is safe for consumption without fear of illness associated with very high levels of copper in human food. Although toxicity of copper is rare, it's metabolism is enhanced by molybdenum and zinc constituents in the body. FLVs growers and collectors need avoid sourcing FLVs from environments and soils contaminated with molybdenum and zinc to reduce the intake of such trace elements and consequently reduce the concentration of copper available in the body.

Primary source of Cadmium $(\mathrm{Cd})$ in human body is through consumption of food grown in contaminated areas and if taken over a relative long time can cause renal, prostrate and ovarian cancers (Turkdogan et al., 2002). Cadmium accumulates primarily in the kidneys and has a long biological half-life in humans of 10-35 years. Critical cadmium level in the kidney of $200 \mathrm{mg} / \mathrm{kg}$ is capable of causing renal failure in adults; however this condition occurs after a daily dietary intake of about $175 \mu \mathrm{g}$ per person for 50 years. JECFA (2005) advised a permissible tolerable weekly intake (PTWI) of $0.007 \mathrm{mg} / \mathrm{kg}$ of body weight. The provisional tolerable weekly intake (PTWI) of $7 \mu \mathrm{g} / \mathrm{kg}$ of body weight was suggested.

Table 1 revealed that samples of all the FLVs contained lesser concentrations of cadmium compared to the PTWI of $7 \mu \mathrm{g} / \mathrm{kg}$, maximum level of cadmium was obtained in Heinsia crinata $(0.076 \mathrm{ppm})$ and the least in Ocimum gratissimum $(0.022 \mathrm{ppm})$ this indicate safety in the consumption of the FLVs despite oil explorations in the study area.

Arsenic (As) is not known as an essential elements in man, however regulated quantities may be added to animal feeds for improved growth in pigs and poultry. Large quantities of Arsenic compounds can cause food poisoning in man. Satsananan, (2014) noted that arsenic contamination can harm food digestion and blood vessels system, central nerves system and spinal cord, causing red blood cell 
damage, it is also implicated for liver damage and could pose risk of cancer to lung and kidney. Morrison et al., (1989) and Yost et al., (2004) asserted that inorganic Arsenic compounds (III and IV) are far more toxic and potent human carcinogen than organic Arsenic compounds. Maximum permissible limits in dietary components range between 0.025 to $0.033 \mathrm{mg} / \mathrm{kg}$ body weight (FAO/WHO, 1967) and permissible tolerable weekly intake (PTWI) of $0.015 \mathrm{mg} / \mathrm{kg}$ body weight for adult (JECFA, 2005). Concentrations of arsenic in FLVs in this study were lower than the maximum permissible limits in all the samples except P.guineense and O.bassilicum which their concentrations were $\quad 0.025 \mathrm{mg} / \mathrm{kg}$ and $0.015 \mathrm{mg} / \mathrm{kg}$ respectively. Excessive consumption of these two FLVs may expose populations in Port Harcourt to health risks from arsenic.

Cobalt (Co) induces a rise in hemoglobin in anemic patients with nephritis, cancer and chronic infections. Normal daily intake of $\mathrm{Co}$ is reported to be in the range of 2.5 to $3.0 \mu \mathrm{g} / \mathrm{day}$. Results showed concentrations within safe daily intake limits, implying no toxicological hazard expected from cobalt on the consumers of FLVs.

Mercury $(\mathrm{Hg})$ has been implicated for abnormalities in children (Gibb and Chen, 1989). Mercury is a cumulative poison and serves no essential function in man. Alfred et al., (2004) reported long term exposure could cause renal dysfunction and neurological symptoms in people working in environment polluted with mercury beyond $0.1 \mathrm{mg} / \mathrm{m}^{3}$. Mercury causes poor reproductive capacity, hypertension, tumour and hepatic dysfunction (Iwegbue, 2010). Permissible tolerable weekly intake suggested by WHO (1993) is $0.5 \mathrm{mg} / \mathrm{kg}$ body weight, none of the values obtained for FLVs in Table 1 is up to the weekly intake allowed for mercury.

Zinc $(\mathrm{Zn})$ is readily absorbed by plants from polluted environments which are subsequently eaten by man. It is an essential element for living organisms for its involvement in a large number of enzymes and stabilizing molecular structures of membranes (WHO, 1996). It participates in the synthesis and metabolism of lipids, carbohydrates and proteins. $\mathrm{Zn}$ has the capability to interfere with metabolism of other metals such as Copper (Cu). Salgueiro et al., (2000) and Odebunmi et al., (2004) hinted that high concentration of $\mathrm{Zn}$ may be carcinogenic and capable of causing vascular shock, dyspeptic nausea, pancreatitis, damage of hepatic parenchyma among other ailments in man and animals. Hambidge, (1987) noted $\mathrm{Zn}$ deficiency could lead to stunted growth in humans and delay in sexual maturation. (EVM, 2003) suggested safe upper limit (SUL) for $\mathrm{Zn}$ as $4.2 \mathrm{mg} /$ day (equivalent to $700 \mu \mathrm{g} / \mathrm{kg}$ body weight/day in a $60 \mathrm{~kg}$ adult) for total dietary intake while WHO (1993) recommended $50 \mathrm{mg} / \mathrm{kg}$ as permissible tolerable weekly intake. Considering the zinc concentration in FLVs assessed in Table 1, the FLVs could be adjudged to be safe for consumption and free of toxicological threat from zinc compounds. 
Table 1: Heavy Metals concentration (ppm) in local forest leafy vegetables in Port Harcourt, Nigeria

\begin{tabular}{|c|c|c|c|c|c|c|c|c|c|c|c|c|c|}
\hline Leafy vegetables species & $\mathrm{Fe}$ & $\mathrm{Mn}$ & $\mathrm{Mg}$ & $\mathrm{Pb}$ & $\mathrm{Cu}$ & $\mathrm{Cd}$ & As & $\mathrm{Co}$ & $\mathrm{Hg}$ & $\mathrm{Zn}$ & $\mathrm{Cr}$ & $\mathrm{Se}$ & $\mathrm{Ni}$ \\
\hline Ocimum gratissimum (L.)Lamiaceae & 8.87 & 0.45 & 1.630 & 0.725 & 0.218 & 0.022 & 0.003 & 0.343 & 0.002 & 0.044 & 1.473 & 0.028 & 0.416 \\
\hline Ocimum bassilicum (L.)Lamiaceae & 7.63 & 0.50 & 1.308 & 0.380 & 0.970 & 0.032 & 0.015 & 0.118 & 0.014 & 0.055 & 2.615 & 0.061 & 0.665 \\
\hline Pterocarpus soyauxii(Jacq.) Fabaceae & 6.72 & 0.74 & 0.805 & 0.777 & 0.375 & 0.028 & 0.009 & 0.197 & 0.005 & 0.053 & 1.464 & 0.024 & 0.527 \\
\hline Piper guineense(L.) Piperaceae & 5.80 & 0.54 & 1.235 & 1.004 & 0.936 & 0.025 & 0.025 & 0.180 & 0.017 & 0.068 & 3.792 & 0.033 & 0.614 \\
\hline $\begin{array}{l}\text { Gongronema latifolia (Benth.) } \\
\text { Asclepiadaceae }\end{array}$ & 8.97 & 4.29 & 1.556 & 0.648 & 0.718 & 0.056 & 0.006 & 0.091 & 0.008 & 0.046 & 1.959 & 0.021 & 0.388 \\
\hline $\begin{array}{l}\text { Liasanthera africana (P. Beauv.) } \\
\text { Icacinaceae }\end{array}$ & 7.18 & 6.03 & 0.609 & 0.603 & 0.629 & 0.057 & 0.008 & 0.104 & 0.013 & 0.057 & 2.106 & 0.049 & 0.496 \\
\hline Heinsia crinata (Afzel.) Rubiaceae & 4.69 & 1.08 & 1.321 & 0.468 & 1.165 & 0.076 & 0.012 & 0.097 & 0.009 & 0.061 & 0.409 & 0.066 & 0.516 \\
\hline $\begin{array}{l}\text { Gnetum africana (Welw.) } \\
\text { Gnetaceae }\end{array}$ & 6.88 & 4.05 & 1.330 & 0.172 & 0.995 & 0.058 & 0.008 & 0.058 & 0.01 & 0.045 & 3.743 & 0.053 & 0.519 \\
\hline
\end{tabular}


Chromium (III) is an essential element for healthy growth while Chromium (VI) compounds are toxics and carcinogenic in humans. Elevated levels can lead to asthma and shortness of breath while long term exposure damage the liver and kidney. Recommended Daily Allowances for chromium as 50-200 $\mu \mathrm{g} /$ day for adult men and women. Chromium levels in the FLVs are below the recommended value, this makes them a healthy food for normal growth and development. Nickel is essential for growth and reproduction in livestock and man, but could be carcinogenic in high amount in the body. Estimated maximum guideline set by USFDA for Nickel is 70-80 $\mu \mathrm{g} \mathrm{g}^{-1}$ (Iwegbue, 2010). FLVs sold in Port Harcourt have lower levels of Nickel concentration compared to the USFDA recommended levels.

FLVs proximate composition is reflected in Table 2, FLVs are rich in crude protein, fat and crude fibre. O.bassilicum $(21.00 \%)$ was richest in crude protein while H.crinata has the lowest level $(11.55 \%)$, these levels competes favourably with protein content of some commercial fruits in India (Seal, 2011). Crude fibre content of the FLVs range between $11.0 \%$ to $14.0 \%$ for O.bassilicum, P.soyauxii, $G$ latifolia G.africana and O.gratissimum respectively while fat content range between $2.4 \%$ for O.bassilicum and $4.0 \%$ for $H$. crinata. High ash content value is an index of the FLVs richness in minerals. Wild plants provide adequate level of nutrition to people in developing countries where there is high cost and poor living standard. The under utilized wild FLVs have high nutritive potential and provide variety to our diets, (Pradheep et al., 2003). FLV species yield substantial fibre content which has the potential to enhance healthy living by reducing plasma and liver cholesterol concentration. Dietary fibres also help detoxify poisonous metals (Cohn and Cohn, 1996) while adequate protein promotes healthy living. The nutritional contents of FLVs samples were higher than many commercially cultivated leafy vegetables in Lagos and Osun states, Nigeria and compared to cultivated leafy vegetables in Côte D'ivoire (Onwordi et al., 2009; Adeleke and Abiodun, 2010; Oulai et al., 2014). $\mathrm{Mg}$, Se and Ni concentrations were all within the safe limits.

Table 2: Proximate Composition (\%) of local forest leafy vegetables FLVs in Port Harcourt, Nigeria

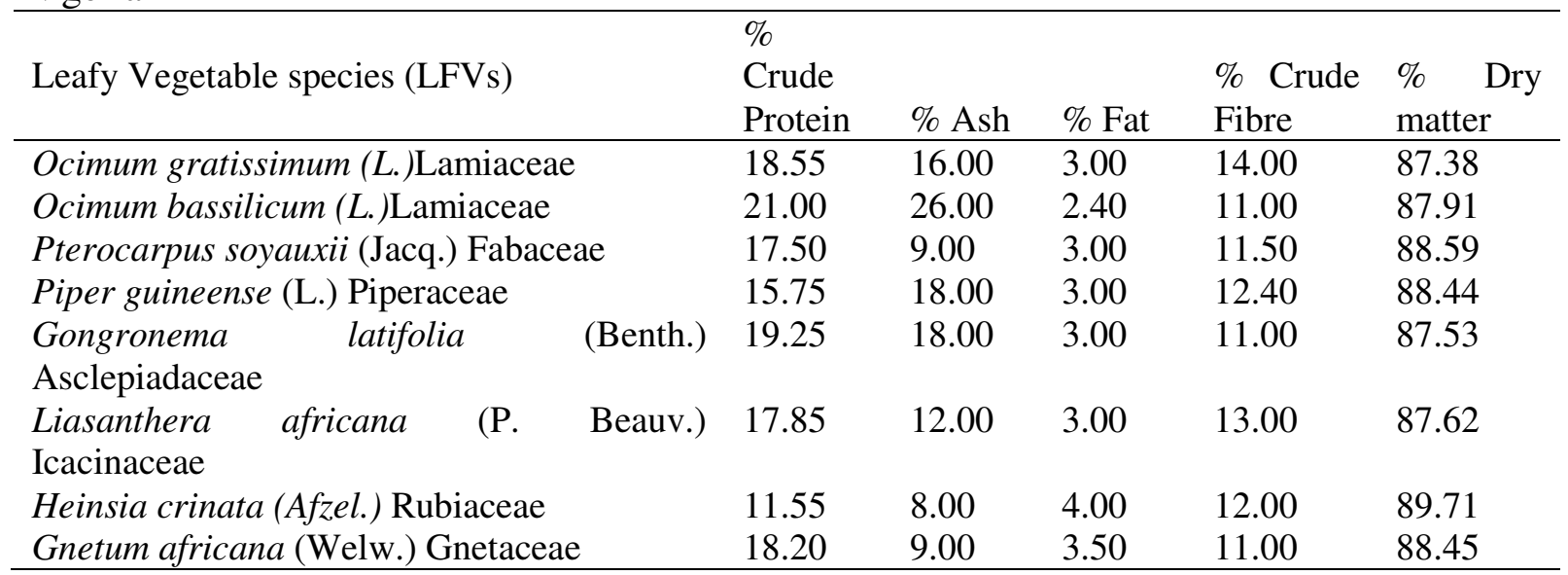




\section{Conclusion}

Various studies globally have linked excessive bio-accumulation of heavy metals to numerous health abnormalities. Heavy metal contamination in the natural environment poses both short and long term environmental health risks. Leafy vegetables produced in open-fields or with contaminated irrigation waters are known to possess high concentration of heavy metals that pose high risk for healthy living. This work revealed that consumption of FLVs sourced from natural forests in crude oil exploration areas in Nigeria is still safe, since heavy metal accumulation of FLVs samples were not up to safe limits recommended by FAO/WHO. Proximate analyses showed that the FLVs possess useful nutritional contents required for healthy growth such as crude protein and fibre. Integration of selected species of FLVs in agro-forestry fields could be a panacea for sustainable food security in developing countries facing food insecurities such as Nigeria.

\section{References}

Aboderin, O.A., Onasanya, L.O., Fasasi, A. and Siyanbola, M. (2010). Levels of Ash, Crude Fat, Some Minerals and Ascorbic Acid in Some Leafy Green and Seed Vegetables Cherished by Most Nigerians. Journal of Tropical Forest Resources, Vol. 26: 33-40

Acharya K.P and Acharya R. (2010). Eating from the Wild: Indigenous Knowledge on Wild Edible Plants in Parroha VDC of Rupandehi District, Central Nepal. International Journal of Social Forestry (IJSF), 2010, 3(1):28-48 ISSN 1979-2611, WwW.ijsf.org

Adeleke R.O. and Abiodun, O.A. (2010). Chemical Composition of Three Traditional Vegetables in Nigeria.
Pakistan Journal of Nutrition 9 (9): 858-860.

Agatha, A.N. (2011). Levels of Some Heavy Metals in Tissues of Bonga Fish, Ethmallosa fimbriata (Bowdich, 1825) from Forcados River. J. Appl. Environ. Biol. Sci., 1(3): 44-47.

Akubugwo, I.E., Obasi, A.N and Ginika, S.C. (2007). Nutritional Potential of the Leaves and Seeds of Black Nightshade - Solanumnigrum L. var.virginicum from Afikpo, Nigeria. Pakistan Journal of Nutrition, 6: 323326

Alfred, B.K., Horvat, M., Prezelj, M., Briski, A.S., Krsnik, M., Dizdarevic, T., Mazej, D., Falnoga, I., Stibilj, V., Arneric, N., Kobal, D. and Osredkar, J. (2004). The Impact of Long-Term Past Exposure to Elemental Mercury on Antioxidative Capacity and Lipid Peroxidation in Mercury miners. Journal of Trace Elements in Medicine and Biology, 17(4): 261274.

Amri, E. and Kisangau, D.P. (2012). Ethnomedicinal study of plants used in villages around Kimboza forest reserve in Morogoro (Tanzania), Journal of Ethnobiology and Ethnomedicine, 144(2): 395-401.

AOAC. (1995). Official methods of analysis (16thedn) Association of Official Analytical Chemists. Virginia, USA.

Awofolu, O.R. (2005). A survey of Trace Metals in vegetation, soil and lower animals along some selected major Roads in metropolitan city of Lagos. Environmental monitoring and Assessment, 105: 431-447

Burlingame, B. (2000)."Wild nutrition." Journal of Food Composition and Analysis, 13:99-100

Cambra, K., Martinez, T., Urzelai, A. and Alonso, E. (1999). Risk analysis of 
farm area near a lead and cadmium contaminated industrial sit. J. Soil. Contam., 8:527-540

Chima, U.D., Oladele, A.T. and Okorie, M.C.F. (2013). Ecological and Ethnomedicinal Survey of Plants within Homesteads in Abia State, Nigeria. Journal of Forest Science, 29(4): 257-274

Driskell J.A. (2009). Upper Safe Levels of Intake for Adults: Vitamins and Minerals. University of Nebrska Lincoln Extension Publication, Institute of Agriculture and Natural Resources,

http://www.ianrpubs.unl.edu/sendIt/g 1981.pdf, Accessed Jan, 17. 2015.

Cohn, R. and Cohn, A.L. (1996). The byproducts of fruit processing in: Fruit processing, ed Arthey D, Ashurst P.R, Chapman \& Hall, London, U.K. pp. 196-220

Expert Group on Vitamins and Minerals (EVM). (2003). Safe upper levels for vitamins and mineral. Report of the Expert Group on Vitamins and Minerals. Food Standards Agency, May 2003. http://www.food.gov.uk/multimedia/p dfs/vitmin2003.pdf

FAO/WHO. (2001). Report on the 32nd Session of the Codex Committee on Food Additives and Contaminants, ALINORM 01/12, Beijing, China, 20-24 March 2000. Joint FAO/WHO Food Standard Programme, Codex Alimentarius Commission, 24th Session, 2-7 July, Geneva, Switzerland.

FAO/WHO. (1967). WHO Technical Report Series No. 373. 10th Report of the Joint FAO/WHO Expert Committee on Food Additives.

Gibb $\mathrm{H}$ and Chen C. (1989). Evaluation of issues relating to the carcinogens risk assessement of Chromium. Science

Total Environ., 86: 181-186

Hambidge, K.M. (1987). Zinc. In: Mertz

$\mathrm{W}$, ed. Trace elements in human and animal nutrition, 5th ed., Vol. 1: 1137, San Diego, FL, Academic Press.

Iwegbue, C.M.A. (2010). Composition and Daily Intakes of Some Trace Metals from Canned Beers in Nigeria, Journal of Institute of Brewing and Distilling. 116(3): 312-315

Jarup, L. (2003). Hazards of heavy metal contamination. British Medical Bulletin. 68: 167-82.

JECFA, (2005). Joint FAO/WHO Expert Committee on Food additives, 64th Meeting, JECFA/64/SC, Codex Standard 193-1995, Pg 47. Accessed from: www.codexalimentarius.org on 26th Feb. 2015

Kaur, R. and Katnoria, J. K. (2014). Heavy Metals and Polycyclic Aromatic Hydrocarbons in Roadside Soil Samples: A review, Int. J. of Environmental, Ecology, Geological and Geophysical Engineering, 8:5

Khanna, S. and Khanna, P. (2011). Assessment of Heavy Metal Contamination in Different Vegetables Grown in and Around Urban Areas. Research Journal of Environmental Toxicology, 5(3): 162179, DOI: 10.3923/rjet.2011.162.179

Lokeshappa, B., Shivpuri, K., Tripathi, V. and Dikshit, A.K. (2012). Assessment of Toxic Metals in Agricultural Produce. Food and Public Health, 2(1): 24-29 DOI: 10.5923/j.fph.20120201.05

Mensah, E., Allen, H.E., Shoji, R., Odai, S.N., Kyei-Baffour, N., Ofori, E. and Mezler, D. (2008). Cadmium (Cd) and lead $(\mathrm{Pb})$ concentrations effects on yields of some vegetables due to uptake from irrigation water in Ghana. Int. J. Agric. Res., 3: 243-251. 
Mohammed, M.I. and Sharif, N. (2011). Mineral composition of some leafy vegetables consumed in Kano, Nigeria. Nigerian Journal of Basic and Applied Science, 19(2): 208-211

Morrison, G.M.P., Batley, G.E. and Florence, T.M. (1989). Metal speciation and toxicity. Chemistry in Britain, 25: 791-794

Nordberg, G.F. (2004). Cadmium and human health: A perspective based on recent studies in China, BioMetals., 17: 485-489

Nriagu, J.O. (1989). A global assessment of natural sources of atmospheric trace metals. Nature, 338(6210):47-49

Nwoko, C.O., Emenyonu, E.N and Umejuru, C.E. (2014). TraceMetal Contamination of Selected Vegetables Grown Around Owerri Municipality, Nigeria. Journal of Agriculture and Ecology Research International 1(1):18-29. www.sciencedomain.org

Odebunmi, E.O., Olutona, G.O., Akintunde, E.A., Faboro, E.O., Balogun, O.S. and Oluwaniyi, O.O. (2014). Trace Metal Levels of Drinking Water Sources in Parts of Osun State, Nigeria. Ethiopian Journal of Environmental Studies and Management 7(6): 635-644. doi: http://dx.doi.org/10.4314/ejesm.v7i6. 6

Ogabiela, E.E., Yebpella, G.G., Adesina, O.B., Udiba, U.U., Ade-Ajayi, F.A., Magomya, A.M., Hammuel, C., Gandu, I. and Mmereole, U.J. and Abdullahi, M. (2011). Assessment of Metals Levels in Cow Blood from Cow's Grazed around Zango, Zaria and Challawa Industrial Estate, Kano - Nigeria. J. Appl. Environ. Biol. Sci., 1(4) 69-73.

Oladele, A.T. and Adewunmi, C.O. (2008). Medicinal Plants Used in The Management of Malaria among the
Traditional Medicine Practitioners (TMP's) in South Western Nigeria. African Journal of Infectious Diseases 2(1): 51-59

Oladele, A.T, Aiyeloja, A.A and Hycent, P.D. (2013). Forest Leafy Vegetables Marketing and Sustainable Rural Livelihood in Rivers State, Nigeria. Journal of Agriculture, Forestry and the Social Sciences (JOAFSS), Vol. 11 , No.1

Onwordi, C.T., Ogungbade, A.M. and Wusu, A.D. (2009). The proximate and mineral composition of three leafy vegetables commonly consumed in Lagos, Nigeria. African Journal of Pure and Applied Chemistry, 3(6): 102-107.

Oulai, .P., Lessoy, Z., Megnanou, R., Doue, R. and Niamke, S.(2014). Proximate Composition and Nutritive Value of Leafy Vegetables Consumed in Northern Côte D'ivoire. European Scientific Journal 10 (6): 212-227

Pande, K.S., and Sharma, S.O. (1999). Distribution of organic matter and toxic metals in sediments of Ramganga River at Moradabad, Poll. Res., vol.18, pp. 43-47

Pradheep, K., Gomez, S.M and Kalamani, A. (2003). Possibilities of broadening the plant wealth of horticulture from existing flora of Tamilnadu, India and Overview. Asian Journal of Plant Sciences, 2: $719-730$.

Redzic, S.J. (2006). "Wild Edible Plants and their Traditional Use in the Human Nutrition in BosniaHerzegovina."Ecology of Food and Nutrition 45:189 - 232.

Salgueiro, M.J., Zubillaga, M., Lysionek, A., Sarabia, M.I., Caro, R., De Paoli, T., Hager, A., Weill, R. and Boccio, J. (2000). Zinc as an essential micronutrient: A Review. Nutrition Research, 20: 737-755. 
Satsananan, C. (2014). The Determination of Heavy Metal in Herb Used in Dusit Community to Develop a Sustainable Quality of Life. International Journal of Environmental, Ecological, Geological and Mining Engineering, 8(5): 288-290.

Seal, T. (2011). Nutritional Composition of Wild Edible Fruits in Melghalaya State of India and Their Ethnobotanical Importance. Research Journal of Botany 6(2): 58-67.

Sekeroglu, N.F., Ozkutlu, M., Dede, M. and Yilmaz, N. (2006). Evaluation of some wild plants aspect of their nutritional values used as vegetable in eastern black sea region of Turkey. Asian Journal of Plant Sciences, 6: 185-189.

Sharma, R.K. and Agrawal, M. (2006). Effects of single and combined treatment of $\mathrm{Cd}$ and $\mathrm{Zn}$ on carrots: uptake and bioaccumulation. Journal of Plant Nutrition. 29(10):1791-1804.

Singh, S. and Kumar, M. (2006). Heavy metal load of soil, water and vegetables in peri-urban Delhi. Environ. Monitor. Assess., 120: 7991.

Sobukola, O.P., Dairo, O.U., Odunewu, A.V. and Fafiolu, B.O. (2007). Thinlayer drying process of some leafy vegetables under open sun. Food Science and Technology, 13(1): 3540.

Song, B., Lei, M., Chen, T., Zheng, Y., Xie, Y., Li, X. and Gao, D. (2009). Assessing the health risk of heavy metals in vegetables to the general population in Beijing, China. Journal of Environmental Sciences, 21: 17021709. DOI: 10.1016/S10010742(08)62476-6

Sundriyal, M., Sundriyal, R.C. and Sharma, E. (2003)."Dietary Use of Wild Plant
Resources in the Sikkim Himalaya, India." Economic Botany 58(4):626638.

Thompson H.C and Kelly W.C. (1999). Vegetable crops. 5th ed., New Publishing Company Ltd, London

Turkdogan M.K, Kilicel F, Kara K, Tuncer I and Uygan I. (2002). Heavy metals in soil, vegetables and fruits in the endemic upper gastrointestinal cancer region of Turkey. Environ. Toxicol. Pharmacol. 13: 175-179.

Watanable, T., Kusamran, W.R, Asanoma, M., Teqsuwan, A., Tantasri, N., Meesiripan, N., Hasei, T., Murahashi, T., Hirayama, T. and Wakabayashi, K. (2005). Mutagenicity of surface soils in urban areas of Aichi Prefecture, Japan and Bangkok, Thailand, Int. J. Health Sci., 51: 645657.

WHO. (1993). 41st Report of the Joint FAO/WHO Expert Committee on Food Additives. WHO Technical Report Series, no. 837. Geneva.

WHO. (1996). Trace elements in human nutrition and health. World Health Organisation, (WHO), Geneva, Pg 160.

Yebpella, G.G., Magomya, A.M., Udiba, U.U., Gandu, I., Amana, S.M., Ugboaja, V.C. and Usman, N.L. (2011). Assessment of $\mathrm{Cd}, \mathrm{Cu}, \mathrm{Mn}$ and $\mathrm{Zn}$ Levels in Soil, Water and Vegetable Grown in Irrigated Farm along River Kubani, Zaria, Nigeria. $J$. Appl. Environ. Biol. Sci., 1(5)84-89

Yost, L.J., Tao, S.H., Egan, S.K., Barraj, L.M., Smith, K.M. and Tsuji, J.S. (2004). Estimation of dietary intake of inorganic arsenic in U.S. children. Human and Ecological Risk Assessment, 10(3): 473-483. 